\title{
Determination and stability of some international screening limited drugs in equine blood by LC-MS/MS
}

\author{
Eylem Funda GÖKTAŞ ${ }^{1, a, \varpi}$, Erol KABíL ${ }^{1, b}$, Ertuğrul GÜNEŞ, ${ }^{1, \mathrm{c}}$, Serol KORKMAZ ${ }^{1, d}$, \\ Tuba Asena KADIOĞLU ${ }^{1, e}$, Ayşen KURT CÜCÜ̈,f \\ ${ }^{11}$ İstanbul Pendik Veterinary Control Institute, Doping Control Laboratory; ${ }^{2}$ Marmara University, Faculty of Pharmacy, Department \\ of Analytical Chemistry, İstanbul, Turkey. \\ a ORCID: 0000-0002-1269-8114; ' ${ }^{\mathrm{a} O R C I D: ~ 0000-0002-0339-0353 ; ~ ' ~ O R C I D: ~ 0000-0001-9872-1882 ; ~}$ \\ dORCID: 0000-0001-8970-6883; ${ }^{\mathrm{e} O R C I D: ~ 0000-0003-2048-9854 ; ~}{ }^{\mathrm{f} O R C I D:}$ 0000-0001-9527-4730. \\ ${ }^{\square}$ Corresponding author: eylemfundagoktas@gmail.com \\ Received date: 13.03.2019- Accepted date: 10.07.2019
}

\begin{abstract}
Stability of some international screening limited therapeutic substances for doping control in equine blood has been investigated with a validated method by using LC-MS/MS after chemical hydrolysis with orthophosphoric acid. Whole blood samples were extracted with a WAX cartridge on auto-SPE. Stability test of the drug substances performed at the same time in working solution and matrix at $+4^{\circ} \mathrm{C},-20^{\circ} \mathrm{C},+20^{\circ} \mathrm{C}$ in dark and $+20^{\circ} \mathrm{C}$ in light conditions for $1,2,3$ and 4 weeks. For short-time stability, the effects of $6 \mathrm{~h}$ storage at $+55^{\circ} \mathrm{C}$ was also investigated. Repeated data were statistically analyzed with ANOVA. All substances in working solution were stable at $-20^{\circ} \mathrm{C}$ and $+4^{\circ} \mathrm{C}$. In the blood matrix, higher temperatures $\left(+20^{\circ} \mathrm{C}\right)$ in light and dark caused degradation of substances at the end of four weeks and short-term study $(\mathrm{P}<0.05)$. In conclusion, these international screening limited substances in blood matrix could be unstable related to temperature and storage time, although in working solution they could be mostly stable in various temperatures for four weeks.
\end{abstract}

Keywords: Doping control, equine blood, LC-MS/MS, stability.

\section{Uluslararası tarama limiti olan bazı ilaçların at kanında LC-MS/MS ile tayini ve stabilitesi}

Özet: Doping kontrolü amacıyla uluslararası tarama limiti kapsamında olan bazı terapötik maddelerin at kanında valide bir metotla LC-MS/MS cihazı kullanılarak stabilitesi araştırılmıştır. Tam kan örneklerinde ortofosforik asitle kimyasal hidroliz sonrasında bir WAX kartuş kullanılarak otomatik katı faz ekstaksiyonuyla ekstrakte edilmiştir. Etken maddelerinin stabilite testi, çalışma çözeltisinde ve matriks içerisinde $+4^{\circ} \mathrm{C},-20^{\circ} \mathrm{C},+20^{\circ} \mathrm{C}$ karanlıkta ve $+20^{\circ} \mathrm{C}$ gün 1 şı̆̆ında $1,2,3$ ve 4 hafta için eşzamanlı olarak çalışılmıştır. Kısa zamanlı stabilite çalışmas $1+55^{\circ} \mathrm{C}$ 'de 6 saat saklamanın etkisini kapsayacak şekilde araştırılmıştır. Yapılan tekrarlı analizler ANOVA ile istatistiksel olarak değerlendirilmiştir. Çalışma çözeltisindeki tüm maddeler $-20^{\circ} \mathrm{C}$ ve $4^{\circ} \mathrm{C}$ 'de stabildi. Işıkta ve karanlıkta yüksek sıcaklık, dört hafta sonunda ve kısa süreli çalışmada kan matriksindeki maddelerin bozunmasına neden olmuştur (P< 0.05). Sonuç olarak, bu uluslararası tarama limitli maddeler sıcaklık ve zamana bağlı olarak kan matriksinde stabil olmayabilirken, çalışma çözeltisinde farklı sıcaklıklarda dört hafta boyunca çoğunlukla stabildir.

Anahtar sözcükler: At kanı, doping kontrol, LC-MS/MS, stabilite.

\section{Introduction}

Most of the doping laboratories that control the samples collected from racing horses are conducting the analysis of prohibited substances according to the International Agreement on Breeding, Racing and Wagering (IABRW) guidance document, which is determined and updated by International Federation of Horseracing Authorities (IFHA) (7). There is no limit level for prohibited substances, however, some endogenous substances in horse metabolism, feed or environmental contaminants have a threshold and therapeutic substances with international screening limits should be analyzed at their specified value as a requirement. The limits for substances are regulated based on therapeutic effects on equines health and prevent their misuse (26). Most of the samples taken from equines are urine and/or blood. When determining the limit values and substances, the type of the sample and drug metabolism are considered. The studied therapeutic substances and the international screening limits in blood are shown in Table 1 . 
Post-race samples are separated into two parts as called A and B (7). Sample A is transported as quickly as possible for doping control. Sample B stored under suitable conditions is analyzed if sample $\mathrm{A}$ is detected as positive. According to the current legislation, blood samples are not frozen and stored in the refrigerator $\left(+4^{\circ} \mathrm{C}\right)$ unless separated to serum or plasma $(7,26)$. The time elapsed between the analysis of sample A and B; the storage conditions of sample $\mathrm{B}$, the description of the effect of temperature changes during transport and consequently knowing the stability of the positive detected substance are critical for the proper interpretation results of the analysis (20). If sample A is identified as positive, sample B should be identifiable in the same manner. In biological fluids sample during storage and transportation, drug concentration could be decreased or increased related to temperature, $\mathrm{pH}$, thermal or chemical degradation, hydrolysis, enzymatic metabolism, compound interference, microbiological or matrix effects $(9,11)$. Due to these effects, confirmatory analysis with sample B, reported as positive before, could be determined as negative. Especially for limited substances, the storage conditions and time are crucial for the quantitative drug presence in the sample to avoid false positive/negative results $(9,11,24,25)$. So, the stability knowledge of the substances in the sample gives vital information about reporting time.

In previous studies, short or long-term stability were conducted in urine $(6,22,23,24,25)$, whole blood $(1,2$, $5,8,12)$, plasma or serum $(1,2,19)$ for doping control $(10$, $18,19,24,25)$, trace element analysis (21) and toxicological researches $(4,5,6)$. Nevertheless, there are few studies were focused on the threshold or limited doping agents except some anabolic steroids (10, 18), diuretics (24) and caffeine (25) in urine matrix. Beside of previous studies, we aimed to analyze the international screening limited Flunixin, Meloxicam, Dembrexine, NButylscopolammonium, Carprofen, Butorphanol, Lidocaine, Mepivacaine, Acepromazine, 7 deuterated internal standards (IS) with the validated method by LCMS/MS and evaluate firstly their stability in diluted working standard and equine blood matrix at different temperatures and conditions in four week period. In addition to that, short-term stability of $6 \mathrm{~h}$ storage at $+55^{\circ} \mathrm{C}$ was investigated as a simulation of hot-day storage effects.

\section{Material and Methods}

Chemicals and standard solutions: Flunixin, Flunixin d3 and Carprofen obtained from Sigma Aldrich (Schnelldorf, Germany); Meloxicam, Dembrexine, Butorphanol tartrate, Scopolamine d3 Hydrobromide trihydrate and Cortisol-9,11,12,12 d4 purchased from Chiron (Chiron AS, Trondheim Norway); Meloxicam d3,
Carprofen-d3, 3-OH Lidokain-d5, 3-OH Mepivacaine-d3, Acepromazine, N-Butylscopolammonium provided from TRC (Toronto Research Chemicals, North York ON, Canada); Mepivacaine obtained from EDQM (Strasbourg, France); Lidocaine was purchased from LGC (Molsheim France). All standards purity was $\geq 98 \%$. Water was purified with an Elga-purelab flex water purification system (Elga-Veolia Water Solutions\&Technologies, UK). n-Hexane was obtained from VWR Chemicals (VWR International Fontenay Sous Bois, France), Ethyl acetate and Methanol were obtained from J.T. Baker (Gliwice, Poland). Potassium dihydrogen phosphate and orthophosphoric acid, acetonitrile (ACN) and formic acid (FA) were purchased from Merck (Darmstadt, Germany). Acetic acid was obtained from Sigma Aldrich (Schnelldorf, Germany). All chemicals were of HPLC grade purity. The solid-phase extraction (SPE) cartridge Oasis Wax (3 cc Vac Cartridge, $60 \mathrm{mg}$ Sorbent per Cartridge, $60 \mu \mathrm{m}$ Particle Size, 100/pk) were obtained from Waters, USA. For sample preparation auto-pipette (Eppendorf Multipette Xstream), vortex mixer (Allsheng MTV-100), laboratory centrifuge (Thermo Scientific Heraeus Cryofuge 5500i), nitrogen evaporator (Biotage Turbo Vab LV), SPE system auto-SPE (Gilson Aspec 274) were used. For storage, Sanyo Medicool (MPR414F) refrigerator and Sanyo Biomedical (MDF-U537D) freezer were used. Blood samples taken from race horses which were determined as negative in the doping control laboratory were used. Permission of the ethics committee was received for this study (Local Ethical Committee for Experimental Animals of Pendik Veterinary Control Institute 03/2019).

Preparation of solutions and instrument conditions: Primary stock standard solutions were prepared in methanol at a concentration of $1 \mathrm{mg} \mathrm{mL}^{-1}$ (Carprofen, Dembrexine, Flunixin, Acepromazine, Lidocaine, Mepivacaine, N-Butylscopolammonium, Butorphanol, Meloxicam d3 (IS), 3 Hydroxy Lidocaine d5 (IS), 3 Hydroxy Mepivacaine d3 (IS), Carprofen d3 (IS) and Scopolamine d3 Hydrobromide trihydrate (IS)), 100 $\mu \mathrm{g} \mathrm{mL}^{-1}$ (Flunixin $\mathrm{d} 3$ and Cortisol d4) except $1 \mathrm{mg} \mathrm{mL}^{-1}$ Meloxicam in DMSO. The working standard mix solution was prepared by dilution of suitable aliquots of primary stock standard solutions and used to spike the blood samples. Cortisol d4 was used as an internal standard for Dembrexine, Acepromazine and Butorphanol. The working solution mix $(10 \mathrm{~mL})$ was contained $0.1 \mu \mathrm{g} \mathrm{mL}^{-1}$ Flunixin, $0.1 \mu \mathrm{g} \mathrm{mL}^{-1}$ Meloxicam, $0.1 \mu \mathrm{g} \mathrm{mL}^{-1}$ Carprofen, $0.002 \mu \mathrm{g} \mathrm{mL}^{-1}$ Acepromazine, $0.002 \mu \mathrm{g} \mathrm{mL}^{-1}$ Lidocaine, $0.5 \mu \mathrm{g} \mathrm{mL}^{-1}$ Dembrexine, $0.005 \mu \mathrm{g} \mathrm{mL}^{-1}$ Mepivacaine, $0.01 \mu \mathrm{g} \mathrm{mL}^{-1} \mathrm{~N}$-Butylscopolammonium , $0.002 \mu \mathrm{g} \mathrm{mL}^{-1}$ Butorphanol. Internal standard mix solution $(10 \mathrm{~mL})$ was contained $5 \mu \mathrm{g} \mathrm{mL}^{-1}$ concentration of deuterated IS. 
Table 1. International screening limits (ISL) of nine drugs recommended by IFHA's Advisory Council on Equine Prohibited Substances and Practices, March 2016 (7).

\begin{tabular}{lc}
\hline Substance & ISL (ng/mL in plasma) \\
\hline Flunixin (FLU) & 1 \\
Meloxicam (MEL) & 1 \\
Dembrexine (DEM) & 5 \\
N-Butylscopolammonium (SCO) & 0.05 \\
Carprofen (CAR) & 100 \\
Butorphanol (BUT) & 0.01 \\
Lidocaine (LID) & 0.05 \\
Mepivacaine (MEP) & 0.05 \\
Acepromazine (ACE) & 0.02 \\
\hline
\end{tabular}

Table 2. Optimisation data of drug substances and internal standards in MRM mode.

\begin{tabular}{|c|c|c|c|c|c|}
\hline Compound Name & Precursor ion & Fragmentor & Product ion & Collision energy & Polarity \\
\hline \multirow{2}{*}{ Meloxicam } & \multirow{2}{*}{352.2} & \multirow{2}{*}{100} & 141 & 15 & \multirow{2}{*}{ Positive } \\
\hline & & & 115 & 16 & \\
\hline \multirow{2}{*}{ Flunixin } & \multirow{2}{*}{297.2} & \multirow{2}{*}{130} & 279 & 21 & \multirow{2}{*}{ Positive } \\
\hline & & & 264 & 33 & \\
\hline \multirow{2}{*}{ Carprofen } & \multirow{2}{*}{274.1} & \multirow{2}{*}{90} & 228 & 9 & \multirow{2}{*}{ Positive } \\
\hline & & & 193 & 31 & \\
\hline \multirow{3}{*}{ Acepromazine } & \multirow{3}{*}{327.3} & \multirow{3}{*}{150} & 254.1 & 20 & \multirow{3}{*}{ Positive } \\
\hline & & & 222.1 & 40 & \\
\hline & & & 86.1 & 20 & \\
\hline \multirow{2}{*}{ Lidocaine } & \multirow{2}{*}{235.3} & \multirow{2}{*}{100} & 86.1 & 11 & \multirow{2}{*}{ Positive } \\
\hline & & & 58.1 & 33 & \\
\hline \multirow{2}{*}{ Dembrexin } & \multirow{2}{*}{378} & \multirow{2}{*}{100} & 262.7 & 25 & \multirow{2}{*}{ Positive } \\
\hline & & & 81 & 25 & \\
\hline \multirow[t]{2}{*}{ Mepivacaine } & \multirow{2}{*}{247.3} & \multirow{2}{*}{110} & 98.1 & 16 & \multirow{2}{*}{ Positive } \\
\hline & & & 70.1 & 48 & \\
\hline \multirow{2}{*}{$\begin{array}{l}\text { N-Butylscopolammonium } \\
\text { Bromide }\end{array}$} & 3602 & 150 & 194 & 16 & Pocitiv \\
\hline & 300.2 & 150 & 103 & 50 & Positive \\
\hline Butorphanol & 3284 & 140 & 310.2 & 20 & Positive \\
\hline & & & 157.1 & 46 & Positive \\
\hline Cortisol D4 & 3672 & 120 & 121 & 21 & Positive \\
\hline & & & 97 & 41 & \\
\hline Flunixin $\mathrm{D} 3$ & 3001 & 140 & 282.1 & 21 & Positive \\
\hline & & & 264.1 & 35 & \\
\hline Scopolamine D3 Hyrobromid & 3072 & 90 & 159.1 & 11 & Positive \\
\hline trihydrate & & & 141 & 27 & \\
\hline 3-OH Menivacaine-D3 & 2662 & 110 & 101.1 & 17 & Positive \\
\hline & & & 73.1 & 37 & Positive \\
\hline 3-OH Lidocaine-D5 & 2562 & 100 & 91.2 & 17 & Positive \\
\hline S-Un LIdocalne-Ds & & & 63.2 & 41 & Fositive \\
\hline Carprofen-d3 & 275 & 80 & 231 & 13 & Negative \\
\hline Carproten-ds & 215 & ou & 228 & 41 & Negatuve \\
\hline Meloxicam-d3 & 3551 & 120 & 141 & 39 & Positive \\
\hline & & & 115 & 9 & rosituve \\
\hline
\end{tabular}


LC-MS/MS analyses were performed on an Agilent series 1200 liquid chromatography (Santa Clara, CA, USA) coupled to 6460 triple-quadrupole mass spectrometer, equipped with an electrospray ionization (ESI) source. The study was modified by Moulard et al. (14) LC MS/MS method. For separation, Sunfire C18 column (Waters, USA) with dimension $2.1 \times 150 \mathrm{~mm}$ and particle size $3.5 \mu \mathrm{m}$ was used. The gradient was applied with $\mathrm{H}_{2} \mathrm{O}-0.1 \%$ FA (phase A) and ACN-0.1\% FA (phase B). The initial conditions of the gradient kept until 5 min was $80 \% \mathrm{~A}$ and $20 \% \mathrm{~B}$. The phase A was decreased to $50 \%$ at $20 \mathrm{~min}$, and at $25 \mathrm{~min}$ to $0 \%$. Such conditions were maintained until $27 \mathrm{~min}$ and the system was reequilibrated with initial compositions of the mobile phase. The total run-time of the method was $31 \mathrm{~min}$. The flow rate was $0.3 \mathrm{~mL} \mathrm{~min}^{-1}$, the injection volume was $20 \mu \mathrm{L}$, and the column temperature was $35^{\circ} \mathrm{C}$. The ESI interface conditions with multiple reaction monitoring (MRM) modes were; the gas temperature $325^{\circ} \mathrm{C}$, gas flow $10 \mathrm{~L}$ $\min ^{-1}\left(\mathrm{~N}_{2}\right)$, sheath gas temperature $350^{\circ} \mathrm{C}$, sheath gas flow $12 \mathrm{~L} \mathrm{~min}^{-1}$, capillary voltage $3.5 \mathrm{kV}$ in negative mode and $4.5 \mathrm{kV}$ in positive mode, nebulizer gas $50 \mathrm{psi}$ and max. pressure limit was 600 bar. Diagnostic ions of drug substances were detected in MRM mode as listed in Table 2 .

Sample preparation: The study was modified by Popot et al. (16) extraction method. $3 \mathrm{~mL}$ whole blood samples plasma into $15 \mathrm{~mL}$ polypropylene tube after centrifuge at $4400 \mathrm{rpm}$ for $15 \mathrm{~min} 30 \mu \mathrm{L}$ of IS mix, 100 $\mu \mathrm{L}$ orthophosphoric acid and $1.5 \mathrm{~mL}$ deionized water was added, mixed in the vortex for $10 \mathrm{~min}$ for hydrolysis. Then, $2.5 \mathrm{~mL}$ phosphate buffer $(0.5 \mathrm{M}, \mathrm{pH} 6.5)$ was added and $\mathrm{pH}$ adjusted to 6 with $5 \% \mathrm{HCl}$. The sample was mixed again and centrifuged (3500 rpm, $15 \mathrm{~min}$ ). The tubes were placed into auto-SPE and preconditioned $(2 \mathrm{~mL}$ deionized water, $2 \mathrm{~mL}$ methanol). The sample was loaded on the cartridge, washed with $3 \mathrm{~mL}$ deionized water/methanol $(95 / 5)$ and dried for 2 min under vacuum then eluted from the cartridge with $3 \mathrm{~mL}$ ethyl acetate/methanol- $2 \%$ acetic acid $(50 / 50)$ and evaporated to dryness $\left(\mathrm{N}_{2}, 45^{\circ} \mathrm{C}\right)$. The dry residue dissolved with $2 \times 100 \mu \mathrm{L}$ methanol, transferred into a glass vial and dried again. $50 \mu \mathrm{L}$ mobile phase solution $\left(80 / 20 \mathrm{H}_{2} \mathrm{O}-0.1 \% \mathrm{FA} / \mathrm{ACN}-0.1 \% \mathrm{FA}\right)$ added and mixed for $3 \mathrm{~min}$ before injected to LC MS-MS.

Stability studies: Stability design have been demonstrated according to 2002/657/EC Commission Decision (3, 15). For this purpose; $60 \mathrm{~mL}$ drug-free blood sample was collected and spiked with mix standard solution and IS mix solution on ISL levels and shaken for $10 \mathrm{~min}$. After that $3 \mathrm{~mL}$ of blood sample was taken and analyzed as fresh solution data for matrix stability. For each storage period, $15 \mathrm{~mL}$ of blood sample divided into glass bottles and stored at $+4 \pm 2^{\circ} \mathrm{C}$ (in the refrigerator), $20 \pm 2^{\circ} \mathrm{C}$ (deep freeze), $+20 \pm 2^{\circ} \mathrm{C}$ in light and $+20 \pm 2^{\circ} \mathrm{C}$ in dark at climate room and temperature controlled with a data logger. The same application was designed for the working solution mix stability with the separation of 750 $\mu \mathrm{L}$ of standard mix solutions to different storage conditions and fresh solution analyzed as initial data for stability test. The aliquots were tested with three replicates after 1, 2, 3 and 4 weeks' storage (estimated reporting time). Short-term stability was evaluated as the influence of $6 \mathrm{~h}$ storage at $+55 \pm 2^{\circ} \mathrm{C}$ for simulating the transfer effects on hot days. $6 \mathrm{~mL}$ of drug-free whole blood spiked with $60 \mu \mathrm{L}$ mix standard solution. $3 \mathrm{~mL}$ was kept in an incubator at $+55 \pm 2^{\circ} \mathrm{C}$ for $6 \mathrm{~h}$ and the other $3 \mathrm{~mL}$ kept at $+4^{\circ} \mathrm{C}$. Then both of them were analyzed together $(n=3)$.

The stability test was designed according to 2002/657/EC, but there is no criterion for the assessment of stability in the guideline. Therefore, for the estimation of the instability of drugs while for the evaluation of degradation over a time period the $\pm 15 \%$ precision acceptance criterion was used (20). In many other stability studies, the results were interpreted according to this criterion $(9,12,13,17,23)$. The results outside the specified criteria are shown on the lines of the graphics. Analysis of Variances (ANOVA) was used for statistical evaluation of the effect of temperature, light-darkness and time of the storage by comparing the initial concentration and measured concentration at varying temperature using SPSS software package (SPSS version 21 for Windows).

\section{Results}

Results of the method for quantitation of some ISL drugs were shown in Figure 1 at the limit level spiked for each drug. The method was used in our laboratories routine analyses and validated according to 2002/657/EC (3). The validation summary for studied substances were shown in Table 3. In the results of validation data, CV \% values were calculated as 1.5-7.2 \% for precision and 1.6$19.7 \%$ for with-in laboratory reproducibility (Table 2).

For estimation of the results, responses of substances were shown depend on temperature and time in Figure 2 and 3. Initial and end of four weeks concentrations were statistically compared in Table 4. Over four weeks, all substances in working solution were stable in conditions of $+4{ }^{\circ} \mathrm{C}$ and $-20^{\circ} \mathrm{C} \quad(\mathrm{P}>\quad 0.05)$. But $\mathrm{N}$ Butylscopolammonium in the light condition of $+20^{\circ} \mathrm{C}$ after $3^{\text {rd }}$ week and Dembrexin in both of light and dark conditions of $+20^{\circ} \mathrm{C}$ after $2^{\text {nd }}$ week deviated out of the criterion of $\pm 15 \%$ (Figure $2, \mathrm{P}<0.05$ ).

In blood matrix, while all substances were stable at $+4^{\circ} \mathrm{C}$ for four weeks (Figure 3, P> 0.05), $\mathrm{N}$ Butylscopolammonium was significantly degraded at $4^{\text {th }}$ week (Table 4, $\mathrm{P}<0.05$ ). There were significant differences in all substances at $+20^{\circ} \mathrm{C}$ in both light and dark conditions when comparing initial data with $4^{\text {th }}$ week data (Table 4, $\mathrm{P}<$ 0.05). In addition, $\mathrm{N}$ - 
Butylscopolammonium, Acepromazine and Carprofen were significantly unstable at $-20^{\circ} \mathrm{C}$ during four weeks (Figure 3, $\mathrm{P}<0.05$ ).

When blood samples were stored at $+55^{\circ} \mathrm{C}$ during six hours for short-term stability, substances (except Flunixin and Carprofen) were degraded at an amount of up to $50 \%$. Though, Flunixin and Carprofen were increased at high temperature (Figure 4).

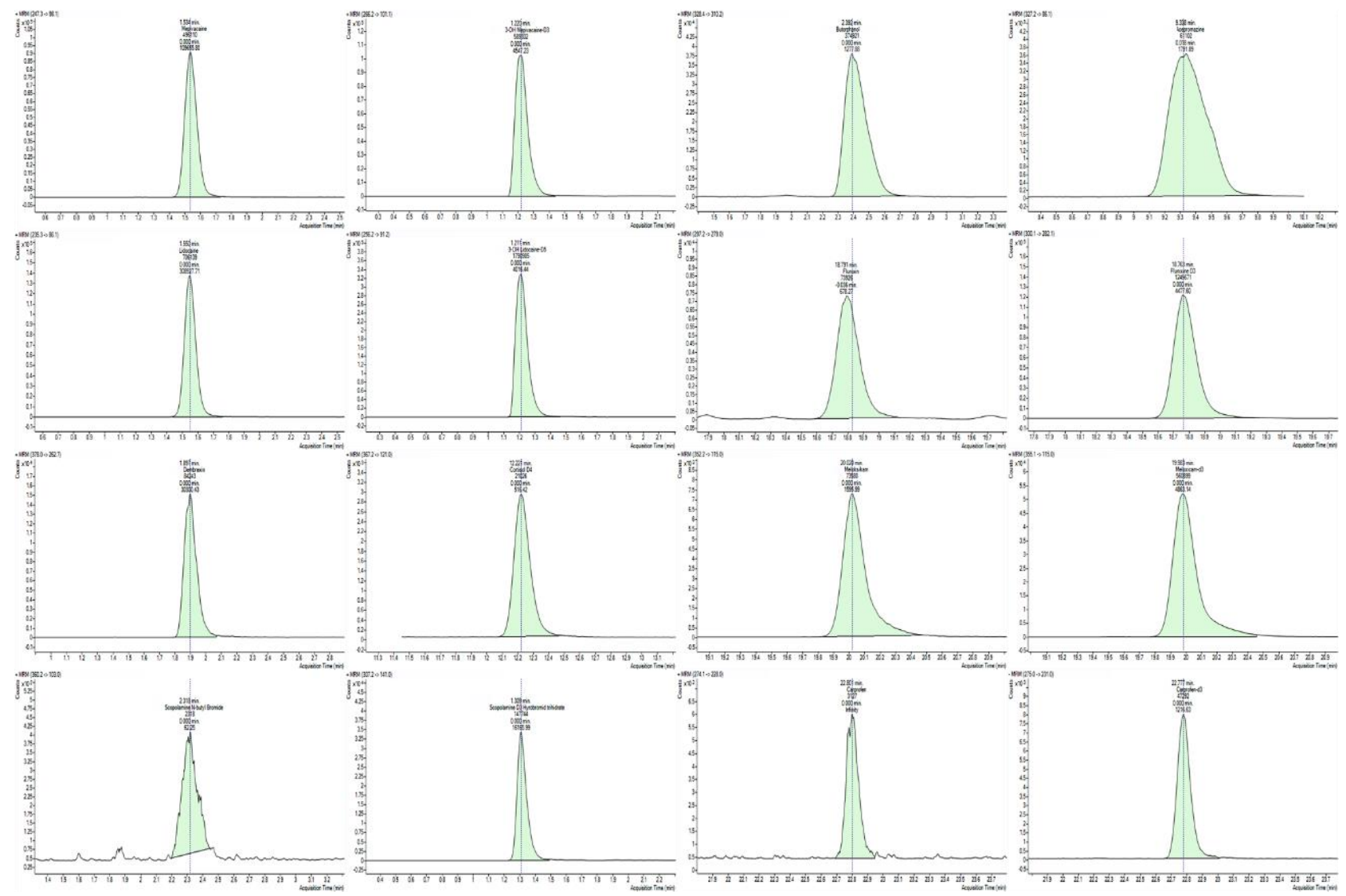

Figure 1. Chromatograms of spiked equine blood samples at ISL levels and internal standards.

Table 3. Results of method validation.

\begin{tabular}{|c|c|c|c|c|c|c|c|c|c|c|}
\hline \multirow[b]{2}{*}{ Substances } & \multirow[b]{2}{*}{$\begin{array}{c}\text { Conc. } \\
\text { spiked } \\
(\mathbf{n g} / \mathbf{m L})\end{array}$} & \multicolumn{3}{|c|}{ Interday $(n=6)$} & \multicolumn{3}{|c|}{ Intraday $(n=18)$} & \multirow[b]{2}{*}{$\begin{array}{l}\text { Within lab. } \\
\text { reproducibility } \\
\text { CV }(\%)^{\mathbf{b}}\end{array}$} & \multirow[b]{2}{*}{$\begin{array}{c}\mathrm{CC} \alpha \\
(\mathrm{ng} / \mathrm{mL}) \\
(\alpha=1 \%)\end{array}$} & \multirow[b]{2}{*}{$\begin{array}{c}C C \beta \\
(\mathrm{ng} / \mathrm{mL}) \\
(\beta=5 \%)\end{array}$} \\
\hline & & $\begin{array}{r}\text { Conc. } \mathbf{m} \\
(\text { mean } \pm \text { SD }\end{array}$ & $\begin{array}{l}\text { leasured } \\
\text { (ng/mL) }\end{array}$ & $\begin{array}{l}\text { Precision } \\
\text { CV }(\%)^{\mathrm{a}}\end{array}$ & $\begin{array}{r}\text { Conc. I } \\
(\text { mean } \pm S\end{array}$ & $\begin{array}{l}\text { neasured } \\
\text { D)(ng/mL) }\end{array}$ & $\begin{array}{c}\text { Precision } \\
\text { CV }(\%)^{\mathrm{a}}\end{array}$ & & & \\
\hline MEP & 0.05 & 0.0494 & \pm 0.0015 & 3.1235 & 0.0496 & \pm 0.0013 & 2.5585 & 3.0827 & 0.0522 & 0.0544 \\
\hline LID & 0.05 & 0.0487 & \pm 0.0010 & 1.9965 & 0.0494 & \pm 0.0012 & 2.4186 & 2.4747 & 0.0520 & 0.0540 \\
\hline DEM & 5.00 & 5.0397 & \pm 0.0799 & 1.5863 & 5.0243 & \pm 0.0841 & 1.6733 & 1.6530 & 5.1385 & 5.2769 \\
\hline $\mathrm{SCO}$ & 0.05 & 0.0492 & \pm 0.0008 & 1.6536 & 0.0492 & $\pm \quad 0.0019$ & 3.9028 & 4.7741 & 0.0537 & 0.0575 \\
\hline BUT & 0.01 & 0.0108 & \pm 0.0006 & 5.4450 & 0.0103 & \pm 0.0007 & 7.1511 & 7.8057 & 0.0113 & 0.0126 \\
\hline $\mathrm{ACE}$ & 0.02 & 0.0195 & \pm 0.0014 & 7.2780 & 0.0205 & \pm 0.0033 & 16.2990 & 19.7906 & 0.0250 & 0.0300 \\
\hline FLU & 1.00 & 1.0272 & \pm 0.0375 & 3.6550 & 0.9970 & $\pm \quad 0.0404$ & 4.0536 & 3.6661 & 1.0596 & 1.1192 \\
\hline MEL & 1.00 & 0.9429 & \pm 0.0550 & 5.8288 & 0.9992 & $\pm \quad 0.0778$ & 7.7836 & 5.5974 & 1.1140 & 1.2279 \\
\hline CAR & 100.00 & 101.6593 & \pm 6.0112 & 5.9131 & 100.2595 & \pm 7.3812 & 7.3621 & 7.8057 & 113.9520 & 127.9039 \\
\hline
\end{tabular}

${ }^{\mathrm{a}}$ For $\geq 10-100 \mathrm{ng} / \mathrm{mL} \mathrm{CV}(\%)$ shall be not exceed 20. For mass fractions lower than $100 \mathrm{ng} / \mathrm{mL}$ the application of the Horwitz Equation gives unacceptable high values. Therefore. the CVs for concentrations lower than $100 \mathrm{ng} / \mathrm{mL}$ shall be as low as possible.

${ }^{\mathrm{b}}$ For $100 \mathrm{ng} / \mathrm{mL} \mathrm{CV}(\%)$ shall be not exceed 23. For mass fractions lower than $100 \mathrm{ng} / \mathrm{mL}$ the application of the Horwitz Equation gives unacceptable high values. Therefore. the CVs for concentrations lower than $100 \mathrm{ng} / \mathrm{mL}$ shall be as low as possible. 


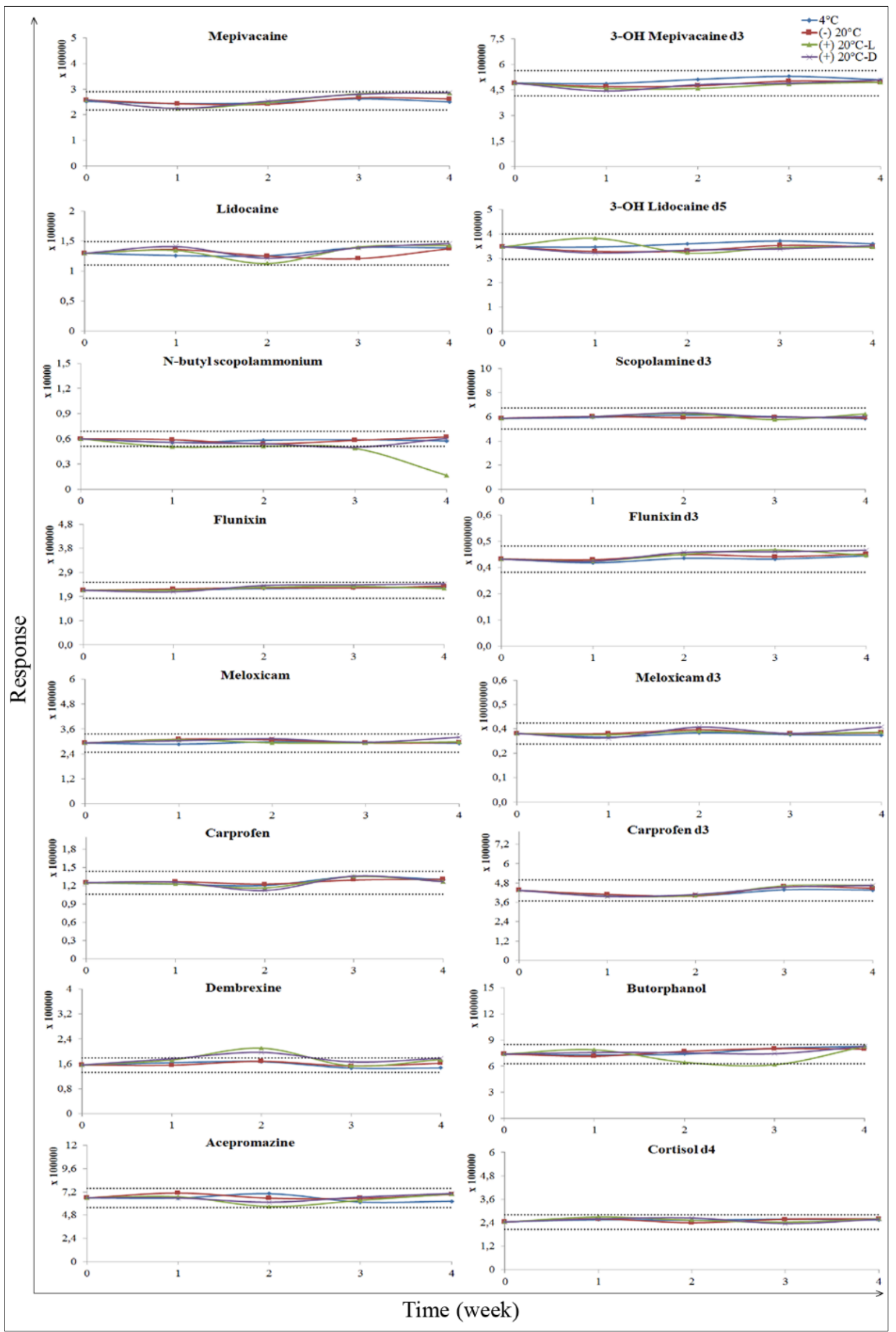

Figure 2. Stability results of working solution mix of nine ISL substances and their internal standards. 


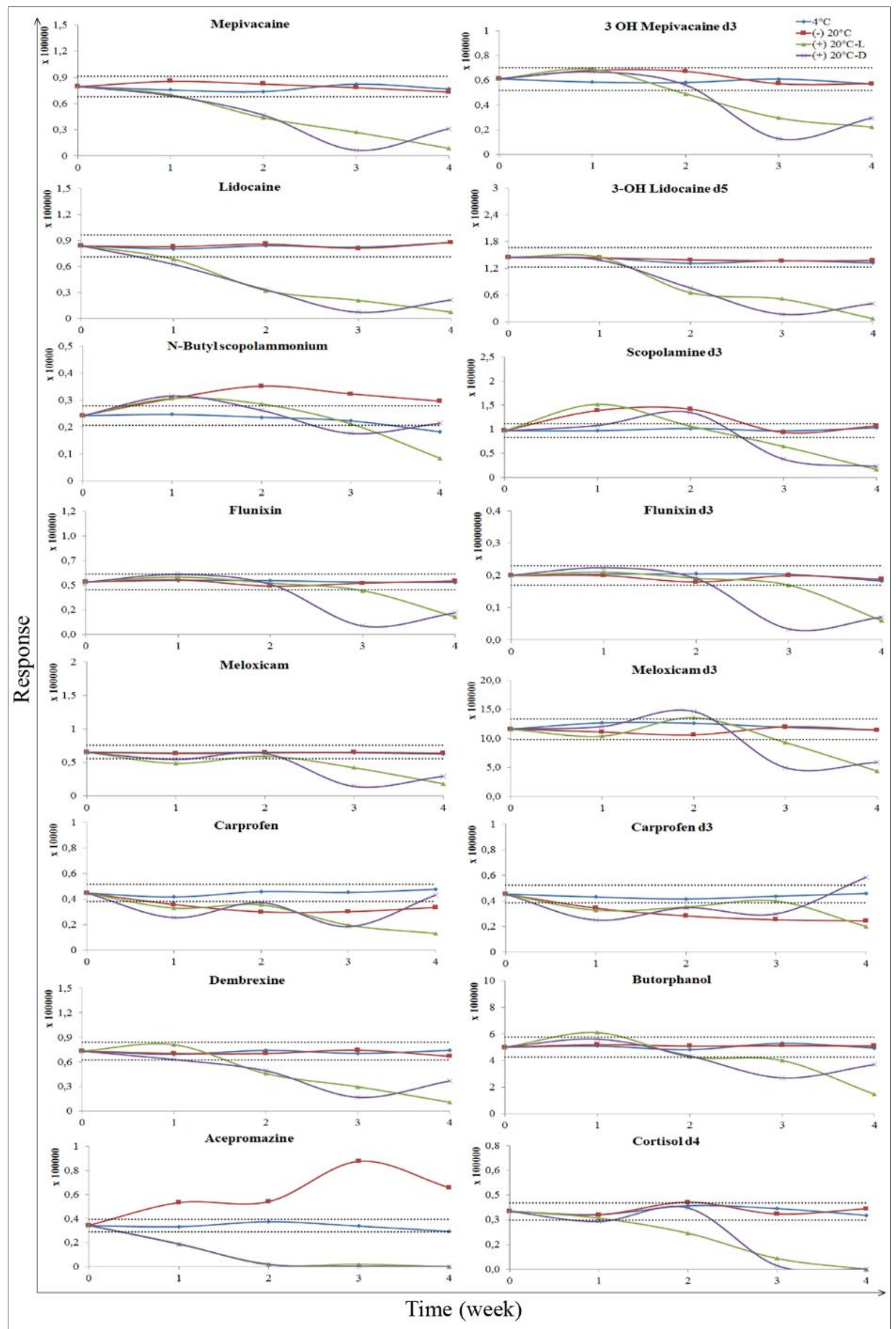

Figure 3. Nine ISL substances and their IS's stability results in blood matrix. 


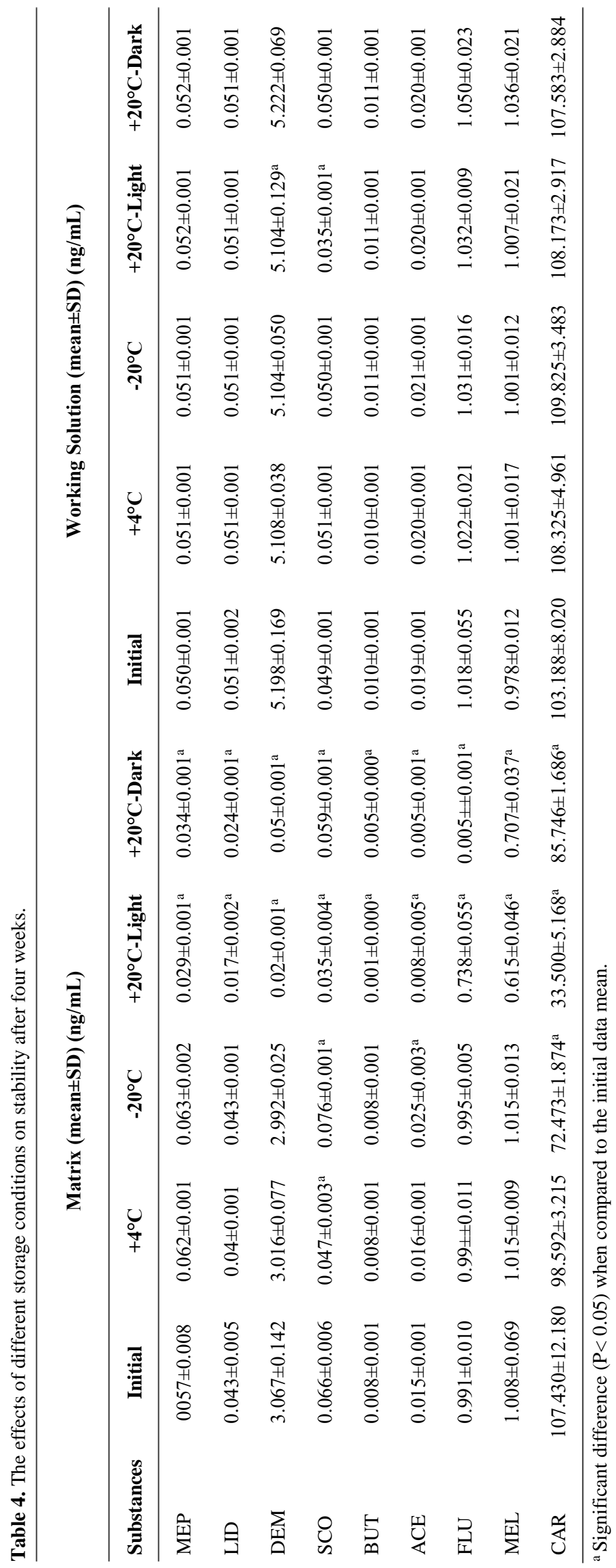




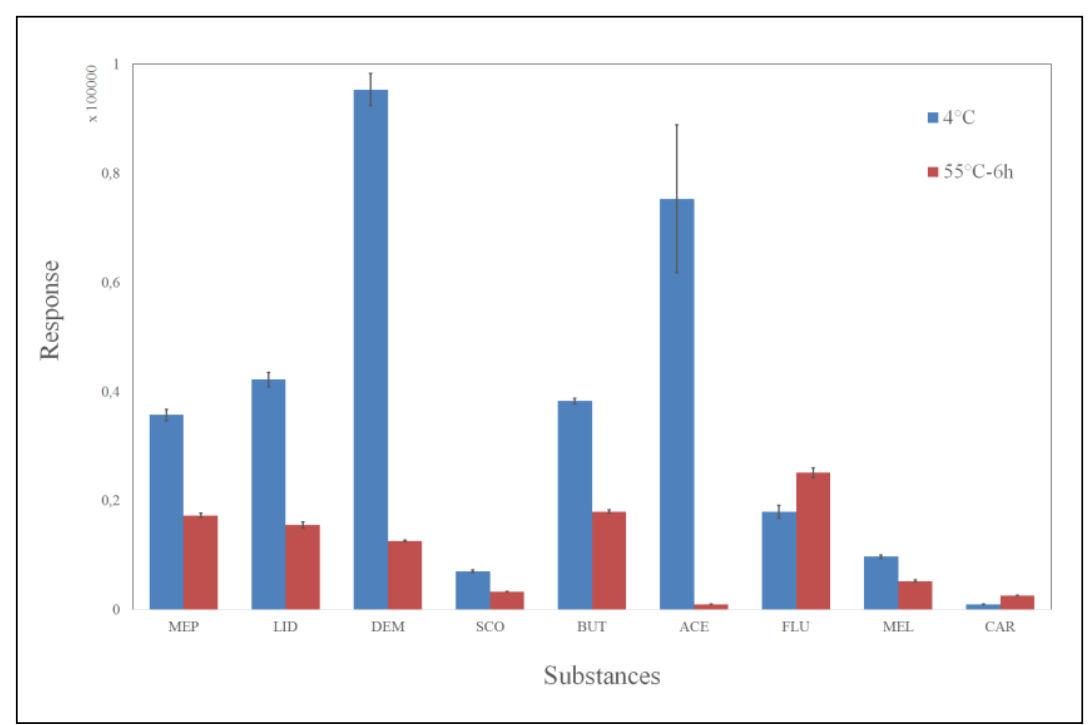

Figure 4. Short-term stability of ISL substances.

\section{Discussion and Conclusion}

The stability knowledge of standards used as references and working solutions at different storage conditions is requisite to check the analysis method and to compare the spiked sample with real sample. For this reason, the stability of both working solution and internal standards used in this study was examined and compared unlike previous studies. Results of this study found out that substances in working solution were stable and matrix effects were clearly occurred related to storage temperature and time. But, at $4^{\text {th }}$ week NButylscopolammonium in working solution was degraded at $+20^{\circ} \mathrm{C}$ in light. Van der Merwe et al. (22) similarly reported that substances can be affected by light.

In blood matrix stability study, reproduction of microorganisms has occurred in the samples kept in $+20^{\circ} \mathrm{C}$ light and dark after $2^{\text {nd }}$ week. The stability of the substances significantly degraded in $+20^{\circ} \mathrm{C}$ conditions in a short time like other studies on urine and blood (19, 22, $24)$. It could be a result of thermal or microbiological degradation (11). Considering the short-term stability study, the samples have a negative effect if the samples are above $+20^{\circ} \mathrm{C}$, hence the results may be misleading.

There were deviations from the criterion value $( \pm 15 \%)$ at $-20^{\circ} \mathrm{C}$ for Acepromazine, Carprofen and $\mathrm{N}$ Butylscopolammonium. Acepromazine showed a negligible increase in concentration overtime during the storage at $-20^{\circ} \mathrm{C}$ (Figure 3 ). This effect could be reinvestigated. The materials used as internal standard are showed similar effects. These results demonstrated that blood samples should not be frozen as indicated on legislation (7). The previous study for 10-week stability in the blood, a decrease of Carprofen $\left(30 \%\right.$ at $\left.-20^{\circ} \mathrm{C}\right)$ and Meloxicam $\left(70 \%\right.$ at $\left.+20^{\circ} \mathrm{C}\right)$ occurred similar to our study, and it was stated that the time between the analyses of $\mathrm{A}$ and B samples was 4 weeks as a proposal (19). However, the instability of N-Butylscopolammonium after the $3^{\text {rd }}$ week, some antipsychotic drugs after $1^{\text {st }}$ week (17) and diuretics after $4^{\text {th }}$ week (24) showed that the analysis time between sample A and B should be kept as short as possible because the substances were differently affected at storage conditions.

Short-term stability demonstrated the high temperature decreased all ISL substances except Flunixin and Carprofen (24). Schenk et al. (19) suggested that the temperature may increase some substances with protein participation. So, the increase of Flunixin and Carprofen might be related to thermo-hydrolysis of proteins in blood matrix.

The best of our knowledge, this is the first report about the stability of ISL substances based on limit value in whole equine blood related to different temperatures, time and light conditions. It was presented the effects of temperature and time on substances in matrix by the comparison of working solution and matrix stabilities. In accordance with results, samples might be stored and transported at $+4^{\circ} \mathrm{C}$ in dark condition and immediately analyzed to avoid false negative/positive results. Future studies about the stability of doping agents may be increased for correct interpretation.

\section{Acknowledgements}

This study was supported by funds from the Republic of Turkey Ministry of Agriculture and Forestry, İstanbul Pendik Veterinary Control Institute.

\section{Conflict of Interest}

The authors declared that there is no conflict of interest. 


\section{References}

1. Atanasov VN, Stoykova S, Runiov A, et al (2012): Stability of diazepam in blood samples at different storage conditions and in the presence of alcohol. Forensic Sci Int, 215, 159-163.

2. Clauwaert KM, Van Bocxlaer JF, De Leenheer AP (2001): Stability study of the designer drugs "MDA, MDMA and MDEA" in water, serum, whole blood, and urine under various storage temperatures. Forensic Sci Int, 124, 36-42.

3. Commission Decision (2002): Concerning the performance of analytical methods and the interpretation of results. European Comission, 2002/657/EC.

4. Dugan S, Bogema S, Schwartz RW, et al (1994): Stability of drugs of abuse in urine samples stored at $-20^{\circ} \mathrm{C}$. J Anal Toxicol, 18, 391-396.

5. Giorgi SN, Meeker JE (1995): A 5-year stability study of common illicit drugs in blood. J Anal Toxicol, 19, 392-8.

6. Hippenstiel MJ, Gerson B (1994): Optimization of storage conditions for cocaine and benzoylecgonine in urine: a review. J Anal Toxicol, 18, 104-109.

7. International Federation of Horseracing Authorities (2019): International agreement on breeding, racing and wagering and appendixes (February 2019).

https://www.ifhaonline.org/resources/ifAgreement.pdf (14 February 2019).

8. Jane Ellis M, Livesey JH, Evans MJ (2003): Hormone stability in human whole blood. Clinical Biochem, 36, 109112.

9. Jiménez C, Ventura R, Segura J, et al (2004): Protocols for stability and homogeneity studies of drugs for its application to doping control. Anal Chim Acta, 515, 323331.

10. Jiménez C, de la Torre R, Segura J, et al (2006): Stability studies of testosterone and epitestosterone glucuronides in urine. Rapid Commun Mass Spectrom, 20, 858-864.

11. Jiménez C, de la Torre R, Ventura M, et al (2006): Stability studies of amphetamine and ephedrine derivatives in urine. J Chromatogr B Analyt Technol Biomed Life Sci, 843, 84-93.

12. Kita K, Ishii T, Hotta K, et al (2018): A dried blood spot assay with UPLC-MS/MS for the simultaneous determination of E6005, a phosphodiesterase 4 inhibitor, and its metabolite in human blood. J Pharm Biomed Anal, 157, 208-216.

13. Moody DE, Monti KM, Spanbauer AC (1999): Longterm stability of abused drugs and antiabuse chemotherapeutical agents stored at $-20^{\circ} \mathrm{C}$. J Anal Toxicol, 6, 535-40.

14. Moulard Y, Bailly-Chouriberry L, Boyer S, et al (2011): Use of benchtop exactive high resolution and high mass accuracy orbitrap mass spectrometer for screening in horse doping control. Anal Chim Acta, 700, 126-136.

15. Peris-Vicente J, Esteve-Romero J, Carda-Broch $S$ (2015): Validation of analytical methods based on chromatographic techniques: An overview. 1757-1808. In: LA Jared, A Berthod, VP Estévez, AM Stalcup (Ed), Analytical Separation Science. Wiley-VCH Verlag GmbH \& Co. KGaA, Germany.

16. Popot MA, Garcia P, Hubert C, et al. (2014): HPLC/ESI$M S(n)$ method for non-amino bisphosphonates: application to the detection of tiludronate in equine plasma. $\mathrm{J}$ Chromatogr B Analyt Technol Biomed Life Sci, 958, 108116.

17. Saar E, Gerostamoulos D, Drummer OH, et al (2012): Assessment of the stability of 30 antipsychotic drugs in stored blood specimens. Forensic Sci Int, 215, 152-158.

18. Saudan C, Entenza JM, Baume N, et al (2006): Shortterm stability of testosterone and epitestosterone conjugates in urine samples: quantification by liquid chromatographylinear ion trap mass spectrometry. J Chromatogr B Analyt Technol Biomed Life Sci, 844, 168-174.

19. Schenk I, Machnik M, Guddat S, et al (2008): Stability of a representative selection of drugs in horse blood. 225-235. In: E Houghton, FI Keskin, JF Wade, N Yazıcioglu (Ed), Proceeding of the $17^{\text {th }}$ International Conference of Racing Analysts and Veterinarians, Antalya, Turkey.

20. Shah VP, Midha KK, Dighe S, et al (1992): Analytical methods validation: Bioavailability, bioequivalence, and pharmacokinetic studies. J Pharm Sci, 81, 309-312.

21. Tevis DS, Jarrett JM, Jones DR, et al. (2018): Assessing the stability of $\mathrm{Cd}, \mathrm{Mn}, \mathrm{Pb}, \mathrm{Se}$, and total $\mathrm{Hg}$ in whole human blood by ICP-DRC-MS as a function of temperature and time. Clin Chim Acta, 485, 1-6.

22. Van der Merwe PJ, Pieterse JW (1994): Stability of zeranol, nandrolone and trenbolone in bovine urine. Analyst, 119, 2651-2653.

23. Van der Merwe PJ, Grobbelaar E (2003): Stability of 19norandrosterone and 19-noretiocholanolone glucuronide in urine under various storage conditions. SA Sports Medicine, 15, 14-17.

24. Van Eenoo P, Lootens L, Spaerkeer A, et al (2007): Results of stability studies with doping agents in urine. $\mathrm{J}$ Anal Toxicol, 31, 543-548.

25. Ventura R, Jiménez C, Closas N, et al (2003): Stability studies of selected doping agents in urine: caffeine. $\mathrm{J}$ Chromatogr B Analyt Technol Biomed Life Sci, 795, 167177.

26. Wong JK, Wan TS (2014): Doping control analyses in horseracing: a clinician's guide. Vet J, 200, 8-16. 